\title{
Loss of Essential Humanity and Empathy as a Result of Exploitations in Blasphemy by Tehmina Durrani
}

\author{
Asma Mubarik \\ National University of Modern Languages, Regional Campus, Faisalabad, Pakistan \\ E-mail: asmamubarik@yahoo.com
}

Doi:10.7575/aiac.alls.v.6n.3p.123

Received: 04/02/2014

URL: http://dx.doi.org/10.7575/aiac.alls.v.6n.3p.123

Accepted: 09/04/2015

\begin{abstract}
After "My Feudal Lord" in 1991, "Blasphemy" is the second major work by Tehmina Durrani; first published in 1998. This book has taken the world by storm since its publication. The novel is a disturbing and agonizing tale of physical and sexual abuse, domestic violence, gender disparity, deterioration of moral and social values, misrepresentation of Islamic ideology, hypocrisy of so called "revered men of God", exploitation of the weak and the disappearance of humanity and loss of empathy as the result of all these evils.
\end{abstract}

Keywords: Blasphemy, Tehmina Durrani, Exploitation; Misrepresentation, Deterioration, Dehumanization, Loss of empathy

\section{Introduction}

The study intends to examine disappearance of essential humanity and empathy as an aftermath of all the exploitations mentioned above. The postmodern theory has been applied by the researcher which according to Dr. Mary Klages states as: "Postmodern art (and thought) favours reflexivity and self-consciousness, fragmentation and discontinuity (especially in narrative structures), ambiguity, simultaneity, and an emphasis on the destructured, decentered, dehumanized subject." The entire novel is an apt example of all the above mentioned aspects of this theory as it clearly indicates the decentred, dehumanized and destructured miserable life of Heer. She was treated so harshly and cruelly throughout her married life that she forgot her true identity, her basic human values, her personal traits, her passion and emotions towards life.

The novel is written in first person from the perspective of the protagonist Heer; Heer who was separated from her Ranjha(beloved) by Khairra (Pir Sain); the so called religious leader and man of God.

The story is set in southern rural Pakistan and explores all the evil practices which a man can think of. The dehumanization and lack of empathy in the character of Heer can be compared to of "Heathcliff" in "Wuthering Heights" by Emily Jane Bronte. The current study intends that the sufferings and exploitations have not only degraded Heer but also have dehumanized her; a freak who can go on to any length of moral decline in order to save herself and her daughters from the further sufferings and exploitations at the hands of Pir Sain.

\section{Literature Review}

"Many forms of expression are required

to break out of the multiple confines that imprison the soul.

Writing and Painting are just two of them". (Tehmina Durrani)

Tehmina Durrani's wrote her autobiography by the name of "My Feudal Lord", published in 1991. It is now translated into 39 languages and is a European Bestseller. The book was the first one in bringing on the surface the unbroken silence of Muslim women, trying to reconcile the rights of women with all principles laid down for them in Islam. But still this book was considered to be before its time.

In 1992 Durrani exhibited her paintings -- Catharsis. One of the paintings became the cover of her third book Blasphemy.

"Believing, those who ruled over our people knew nothing about the core issues that confronted the oppressed, deprived and directionless millions in every corner of the country, she sought out the ONLY man who had spent a lifetime in the service of the downtrodden -- Abdul Satar Edhi. She recorded the thoughts, inspirations, motives, observations and works of Pakistan's most revered and renowned social reformer. It is a guide towards making a personal revolution, which in time would move the collective spirit towards humanitarian Islam. In 1994, A Mirror to the Blind, Mr. Edhi's narrated autobiography, an official document of the Founder of Edhi Foundation.

In 2001 Tehmina Durrani launched The Movement Ana Hadjra Labaek at the Future show 3010 in Bologna, as a futuristic mission to empower women with their Islamic Rights through the Islamic symbol of Hadjra; a peaceful transition to Islam's Original Intention through Ijtehad. 
Happy Things in Sorrow Times is a novel with 38 water colour illustrations done at Afghan refugee camps in Kandahar, Turkham and Chaman. It is the first part of a trilogy. A story told from the heart of a child, Basrabia, in war torn Afghanistan from the time of the Soviet invasion of Afghanistan to the present US War on Terror.

A war, not against soldiers and warriors, but against innocent children. They need another chance in the interest of World Peace."

"I had fallen into the classic trap of the Pakistani woman. The goal is marriage and, once achieved, the future is a life of total subordination. I had no power, no rights, no will of my own." - (Tehmina Durrani)

The above passage has been extracted from her autobiography and it clearly sums up the essence of this book. Tehmina's tale is the classic instance of women in Muslim society; the women who are driven into years of slavery and trauma in their husbands' households. Their lives are manipulated by the repeated misinterpretation of the teachings of the Islam. During her life with her manipulative husband, Tehmina rebelled many times but this rebellion was constantly drawn into a web of intrigues then resultantly; self-denial.

“ Durrani's book, My Feudal Lord, has been criticized for its writing style, and yet the book is absolutely engaging and provides a great insight into the politics of Pakistan - from the reign of Bhutto, to the military regime of General Zia and then to the rise of Benazir Bhutto. And amidst this great political drama of the early stages of Pakistani history, is the heart-rending tale of Tehmina Durrani. It is the efforts of this brave woman that this tale has been shared globally, providing first-hand glimpses of the vulnerable position of women caught in the complex world of feudal society." (felinemusings.com)

"Blasphemy" by Tehmina Durrani has horrified many when it speaks on the very first page; "This novel is inspired by a true story". Though it is a combination of fact and fiction, yet it has produced some controversies. It was feared to be banned as it exposes the hypocrite Muslim religious leaders who exploit the innocent public in the name of Islam. It explores the lives of those miserable creatures called 'wives' in general whose lives are so much tormented and despicable in the end that majority of them even forget their inviduality and true identity. They become puppets in the hands of their overpowering 'demy gods' and spend their whole lives in the prisons of their choking households.

Heer, the protagonist, after all the sufferings and exploitations, has herself become a hollow and petty creature, crawling on all fours, going to any extent for her survival in the tyrant household of Pir Sain(the so called reverent man of God).For saving her daughters from the incest cast upon them by their evil and sadistic father, she has completely lost her humanity and empathy for the orphans, miserable creatures and downtrodden. Just like Heathcliff in Wuthering Heights, she is torn into conflicts; the internal conflict which constantly reminds her of her wrong doings, and the external conflict which forces her to justify her tyrannical deeds.

Heathcliff constantly thinks of revenge against his tormentor Hindley after suffering throughout his childhood and youth at his hands. He was robbed off the love of his life, lost his self identity and individuality, was treated as a slave and was nothing more than a creature for the sadistic pleasures of the people around him. He became what his circumstances taught him; a devil and evil spirit in himself. He vowed on many occasions for the revenge he nurtured all his life:

"I am trying to settle how I shall pay Hindley back. I don't care how long I wait, if I can only do it at last. I hope he will not die before I do!"(Wuthering Heights-7.69)

Same are the feelings of hatred and revenge which Heer harboured against Pir Sain and she expressed these feelings time and again:

"My death wish for Pir Sain overwhelmed my senses.....When he swallowed; I prayed it stick in his throat. When he drank, I prayed that he choke. When he slept, I stayed awake; hoping his heart would stop. (Durrani, 2000.pg 177)

\section{Research Methodology}

The present research is qualitative in nature. The methodology to survey the novel with critical lens is largely based on analyzing the text. The critical survey is based on the theory of postmodernism and the original text of the novel has been used as a tool by the researcher. In addition, other related literary pieces, articles, books, reviews on the novel in question and websites have been used as sources for help in throwing light on the given topic.

\section{Findings, Discussion and critical survey of the text}

"Blasphemy" is replete with the instances which throw ample light on the barefoot journey of a tormented soul to a soulless and futile destination.

"Victimized by her tormentor in her early teens, Heer sees the worst kind of sexual, physical, mental and emotional agony as she tries to coexist with Pir Sain in his household as nothing more than a lurking shadow". (Saumya Kulshrestha).

This torment has led Heer to do what she abhorred if she were living in normal circumstances. Her meagre but respectable upbringing made her keep silent when her mother planned to get her married to much older Pir Sain. The insecurity of her mother after being a widow made Heer understand the miserable financial plight of her household. The marriage to Pir Sain was thought to be a blessing in disguise for the secure future of her rest of the siblings and she accepted her fate as it was doomed upon her. She even left her passion of love at first sight towards her friend's brother 'Ranjha' and just like a typical eastern girl of a middle class family, accepted the proposal even without raising a meek voice of protest or displeasure. 
The novel starts with reminiscence; from present to past memories. The memories which bring with them the tales of horror and terror, the helplessness and misery, the pain and ache of being tormented, the urge to die and the urge to live for kids, the urge to get free and the urge to take refuge in mother's comforting arms, the memories of choking four walls of Pir sain's home and the memories of the dark side of her own soul. The selfishness of her own being which has left her all but empty handed, devoid of empathy and mercy; a constant conflicted soul.

The initial sufferings at the hands of Pir Sain made Heer learn clearly the art of survival in an oppressing and frightful household.

"Survival meant avoiding the master's wrath.” (Durrani, 2000.p.51)

The avoidance of this wrath was her sole concern which led her to understand and devise her own strategies. 'I realized that the suppressed derived strength from suppressing others. It helped them to accept their own imprisonment and was an easy occupation for the trapped'. (Durrani, 2000.P.51)

Pir Sain exploited the weak whenever he wanted. By imposing strict norms of "Purdah"(veil), he confined the women of his family within the four walls of his "Haveli"(mansion). But it was the same "Purdah" which he madly and wildly ripped off each night, each noon and sometimes twice or thrice in a day.

It was the same guise of "man of God" under which incest infested the family, daughters were molested by their fathers, and issueless couples were "blessed" with children miraculously after prayer by Pir Sain, where every maid servant of tender age was considered to be blessed in the service of reverent Pir Sain.

This was the practice of incest which led Heer to save her daughters from the ferocious and indefatigable sexual appetite and lust of their father.

She was mortified by the chilling and horrific enterprise of Pir Sain when he laid his lustful hands on his twelve years old daughter "Guppi". Already tormented by the incestuous relationship of one of Pir Sain's brother with his own daughter (Meesni), Heer was horrified beyond bounds.

"Fear, shock, anger and confusion spread from my head, through my body, into my feet, and darted back up again. Meesni's secret life, buried in her father's haveli had always haunted ours like ghost. Now it came alive". (Durrani, 2000.pg.111)

It was the fear which sowed the plantings of selfishness and dire urge of survival, no matter at what cost, in the heart of Heer. She suffered from guilt and anxiety at her horrendous and abhorrent accomplice ship in the cruel and tyrannical deeds of Pir Sain.

She produces an orphan girl "Yathimri" in front of Pir Sain in order to divert his attention from Guppi. She was relieved when Pir Sain accepted Yathimri as new bait to nibble upon. She harnessed her sense of guilt at her selfishness by the thought that "Child rape was a lesser evil than incest". (Durrani, 2000, p, 112)

She maintained her composure even at the sight of small orphan girl, brutally shattered by the lusty claws of Pir Sain.

"His eyes bored into me, searching to catch a glimpse of sympathy for her and disapproval of him. He saw nothing." (Durrani, 2000.pg.112)

She was worried that she had satiated the hunger of Pir Sain for now; what she would next if he planned to plunge again on some other young girl? So, the mild inclination of sending Yathimri to some safe heavens vanished completely she thought Guppi in place of Yathimri. She was in deep conflict. She knew what she had done but the urge to save her own daughters hardened her heart towards Yathimri. She thought to keep the orphan girl in Pir Sain's service.

"She had been through the worst the first time. I would feed her well and make her strong to face the rest. My heart softened towards her, but hardened when it softened towards Guppi.” (Durrani, 2000. p.114)

In the heart of her heart, she knew that it won't be the first and last endeavour of Pir Sain. She had to send the child in his service again and again. But her thoughts only hovered around the safety of her own daughters.

"Oh Allah!” I worried, "will she sustain his lust until all my daughters are married? Will I sustain the evil”? (Durrani, 2000.pg.115)

The soft feelings towards Yathimri instantly turned into envy and jealousy when the orphan girl won Pir Sain's favour. Heer felt at competition with all the young maid servants at home when she was realized by Pir Sain sarcastically that youth has no substitute. She did everything to dispel favour of Pir Sain from Yathimiri and gloated over victory when the orphan girl was once mistreated by Pir Sain. Heer's heart didn't bleed at all for the orphan girl any more. Yathimri was an enemy and rival now and enemies do not deserve sympathy and empathy. Heer herself proclaimed after all this chaos:

“A conscience had no place in my life." (Durrani, 2000.p.123)

Her heart was further torn into pieces with sympathy for her own daughters when Guppi consoled her as if everything Heer did was justified:

“Amma, don't feel guilty for the choice you made. You replaced the impossible with possible. Whereas Yathimri is Jaiz (legal) for my father, I am not. She can be Halal (lawful), for he can marry her. I can only be Haraam(forbidden act).” (Durrani, 2000.pg126) 
When a widow with her two young daughters pleaded for shelter in haveli, Heer's eyes cast upon the new bait to be presented to Pir Sain.

"Guilt knocked on my mind. I kicked it out.....I was leading the widow's lamb for slaughter instead of slaughtering my own lambs." (Durrani, 2000.p.127)

This thought is reverberated in the words of Heer's mother while deciding the menu at her wedding. The words seem ordinary but carry great irony and symbolic interpretation when evaluated with deep insight:

"Slaughter young goats only, they are more costly but worth their price.”(Durrani, 2000.p.30)

No one except Heer could know the price she paid while slaughtering young lambs (young girls) at the altar of Pir Sain. She tried to satisfy widow's needs by providing her with money time to time. She soon realized that widow was aware of all the lurking in the household regarding her own two daughters. This thing eased Heer's guilt at cheating another mother (widow).

At prayer time, she cried inconsolably at her prayer mat to God about her guilty conscience. But in the morgue like household, she was an accomplice in Pir Sain's satanic deeds.

She yearned to seek comfort in her mother's arms but she was always deprived of this innocent privilege. Her mother sacrificed her to Pir Sain for the better social status and secure future of her rest of three children.

Suffering at the hands of Pir Sain, Heer knew nothing except saving her daughters and herself. She lost all her desires of living a free life. Her relentless battle was to save scrapes of her honour left yet. She turned into a creature that misery and torment had hardened at the core. She soon realized the fact of the day that:

"The most reliable relationships are unreliable." (Durrani, 2000.p.74)

She continued to serve Pir Sain the 'young lambs' and became so accustomed to it that once the death of a small girl under the oppression of Pir Sain didn't bother her at all. She didn't care for the burial or the aftermath of child's death and within minutes of the tragedy, she hurried off to shrine. She became so depressed and senseless at times that she prayed to God for Pir Sain's or her own death.

"I was resigned to finding peace either in my own, or in my husband's death."

(Durrani, 2000.p. 172)

She was so frustrated that even the sight of a female spider stinging its male partner to death raced her mind with the thoughts of her husband's murder.

When a figure in white robes met her at shrine and asked her wish in life, without thinking for a moment about the consequences and suspecting the identity of the figure, she openly blurted out:

"I want my husband's death." (Durrani, 2000.p.172)

She patiently became an accomplice in the murder plan of Pir Sain with this unknown figure. When the murder took place, she was relieved completely. Her gestures were not of a widow but of a prisoner, freed out of prison.

"Pir Sain was dead. I sat in his armchair. I had never seen him. He had never let me. Now, I stared at his dead face. It was over. I lit a cigarette and inhaled deeply." (Durrani, 2000.p.184)

When the people crying and wailing at Pir Sain's death surrounded her, she consumed sedatives and nicotine as "Crying was always easy under the influence of drugs." (Durrani, 2000.p.186)

She locked herself inside the room, produced a packet of cigarette and inhaled nicotine profusely. For her, the din outside, was nothing but merely a play:

"Death, in our part of the world, always made people theatrical. They believed that the extent of loss is determined by an exaggerated display of emotion."(Durrani, 2000.p.14)

She was disgusted when the people lamented and beat their breasts at the death of Pir Sain. "May Allah give you patience to live a long life without a husband." For her; it was "The ultimate curse." (Durrani, 2000.pg.13)

After spending twenty four years of an imprisoned life with Pir Sain, Heer had long ago learnt the ways of a crooked life. She learnt to shut up the intrigues and controversies hatching and brooding within the four walls of household.

When her mother and sisters came wailing the death of Pir Sain, Heer soon realized that:

"For the women of haveli it was the commotion that broke their routine without consequence. But the interest with which they watched me was dangerous; they could convert into a beehive of intrigues. I began to weep louder than all of them." (Durrani, 2000.p.18)

For her the haveli was equal to Hades.

"The walls rose high into the sky and enclosed the square space I was doomed to inhabit." (Durrani, 2000.p.45)

Throughout her married life, she was engulfed with conflicts; the guilt of wrong doings and the urge to survive. With Pir Sain, she acted as an accomplice, in isolation, she wept frantically for her satanic ventures. Pir Sain's oppression and satanic cult left Heer devoid of empathy. She felt the pain of other poor, afflicted and victimized women in the haveli. She considered herself and these women in the same boat under the cruel and tyrant Pir Sain. But when the question arose of her own survival and the safety of her daughters from the clutches of nefarious and abhorrent practice of incest; 
her heart hardened towards them. She led the poor creatures into Pir Sain's chamber in the darkness of night. She consoled herself with her own devised justifications. In the morning, she felt pity for the 'young lambs'. In the night, she preyed them to satiate the never ending sexual appetite of Pir Sain. She herself indulged in the practices she hated the most.

In order to survive Pir Sain's wrath and displeasure, she even served as his pimp. She was compelled by Pir Sain to satisfy the sexual demands of the people of same creed as of her husband.

" Red lipstick, penciled eyebrows, a heavy perfume and I took on the persona of a legalized prostitute....Pir Sain called me 'Piyari' and instructed me to pleasure his friends." (Durrani, 2000.p.165)

\section{Conclusion}

"Blasphemy" is a serious tale of inner darkness of human nature. The abyss of darkness which is disguised with fake illumination is exposed and shattered in its true sense. The exploitation, the suffering, the afflictions, the atrocities, the pain, the torment, the turmoil, the chaos, and most of all, the loss of essential humanity and empathy as the consequence of all these give a jolt to the minds of readers. They start wondering from where the fiction ends and the facts begin or vice versa. The whole novel seems so bizarre and presents such a macabre look that in first reading it sounds far from reality. But the deep insight leads to the better understanding and circumstances of the protagonist. Then it appears quite natural and in practice in our society. The daily newspapers are replete with these bone chilling stories of domestic violence in many shapes and types.

"Saimah Raza", under the title of "Unsynchronized Thoughts" (July, 2011) has aptly said in her review of the novel: "Life was so difficult for her that at many instances, she had no other choice than to join hands with this satan. Her only motive in life was survival. Heer realized that to fight in this world of evil, she had to be more evil. There was no way out but to keep spinning this endless poisonous loop until either the tormented or the tormentor gives up hope on survival. And one of them does give up. One might call it a happy ending, but after going through so much, for Heer, it would be far from being so."

\section{References}

Bronte, E. (2009). Wuthering Heights. New York: Oxford University Press.

Durrani, T. (2000). Blasphemy. Lahore: Ferozsons Publishers Pvt.Ltd.

Klages, M. (2012). A summary of Postmodernism. Retrieved from http: www.colorado.edu

Kulshreshtha, S. (1991). My Feudal Lord-An extraordinary tale of an ordinary woman. http://felinemusings.com/2008/07/12/my-feudal-lord/-

Raza, S. (2011). Unsynchronized Thoughts. Retrieved from http://saimah-raza.blogspot.com/2011/07/book-reviewblasphemy.html. 